Vol. VII, Fasc. 1 e 2, p. $105-111$.

\title{
ON THE UNEVEN DISTRIBUTION OF THE COPELATA OF THE FERNANDO DE NORONHA AREA
}

(With a map, two figures and a table)

\author{
T. K. S. Bjönberg \& L. Forneris *
}

\section{INTRODUCTION}

The region of Fernando de Noronha Island was visited by Dr. M. Vannucei and Dr. E. F. Nonato in January 1954. Plankton samples were collected in nine stations (see map 1). Fernando de Noronha Island stands at approximately 200 nautical miles off the coast of Brazil at about $4 .^{\circ}$ Lat. S and is surrounded by the northern branch of the South Equatorial Current, with waters of high salinity and high temperature. The island is situated within a well limited region devoid of the typical maximum of salinity found in most of the tropical and subtropical zone of the Atlantic Ocean (Defant, 1936, p. 323, abb. 62). The depth of the tropical thermoclyne is approximately $100 \mathrm{~m}$ coinciding with the maximum of vertical stability. It is therefore considered that the admixture of water from deeper layers is insignificant and consequently the ocean in this region is poor in nutrients and accordingly also in plankton (Hentschel 1933, p. 15, fig. $3 \& 4$ ).

\section{METHODS}

Hauls were made with three types of plankton nets: - a small phytoplankton net (A) $1 \mathrm{~m}$ in length and an opening, the diameter of which was $25 \mathrm{~cm}$, made of Swiss silk guaze n. ${ }^{\circ} 18 \mathrm{XX}$; a small zooplankton net (B) with the same measurements as the preceding net and made of Swiss silk gauze $\mathrm{n}^{\circ} 6 \mathrm{XX}$; a pelagic net (C) $2.90 \mathrm{~m}$ total lenght and with one meter square opening, the filtering portion of the net made of Swiss silk gauze n. $22 \mathrm{GG}$ and n. $^{\circ} 36 \mathrm{GG}$.

* Partially supported by a grant in aid of the National Research Council of Brazil (C. N. Pq.). 
Table 1 shows the number of stations, their position, other data, the nets used and the number and percentage of Copelata found in each sample. These were hauled from surface layers always above the $50 \mathrm{~m}$ depth line and in the northwestern and southwestern approaches of the island.

The differences in the methods of collection and the want of sufficient data made it difficult to convert the numbers of animals of each sample into comparable terms. For this reason the percentages instead of the absolute numbers were used.

Fig. 1 shows the percentage of species occurring in each station, and Fig. 2 shows the same per sample hauled in each station.

\section{SPECIES OCCURRENCE}

The population of the Copelata of the plankton of this area had the following general composition in decreasing percentage of each of the more frequent species: Fritillaria borealis, Haplopleura longicauda, Oikopleura fusiformis, Fritillaria pellucida and Fritillaria formica. The majority of the species are eurythermic thermophiles, enryhaline and panthalassic. The observation of the populations of each station showed that there was a sharp difference between the northwestern and southeastern population.

Among the stations at the southern side of the island we may distinguish two groups based on approximately the same ration of species percentages. They are group I, represented by stations 1 and 7 and group II, represented by stations 2, 8, and. 9. As may be seen in Fig. 1, stations 1 and 7 are characterized in decreasing frequencies by Haplopleura longicauda, Fritillaria borealis (chiefly sargassi), F. pellucida and Oikopleura fusiformis (plus $F$. formica in station 7 ); and stations 2,8 and 9 by $F$. borealis, $H$. longicauda, $O$. fusiformis, $F$. pellucida and $F$. formica. There are only slight differences between the frequencies of $H$. longicauda and $F$. borealis in the stations of groups I and II.

In Fig. 2, which shows the percentages of the species per sample per station, we can observe that in samples M3 (station 1) and M5 (station 2) there is a correspondence of frequencies of the different species obtained with the exception of $F$. pellucida. This species also appears in station 1 (M2). Therefore stations of group I and II of Fig. 1 are here considered as being of the same general nature, with great abundance of $F$. borealis and $H$. longicauda, and the presence in smaller numbers of $O$. fusiformis, $F$. pellucida and $F$. formica. This association was typical of the southern waters of the island at the time when the hauls were made.

The stations on the southern side of the island are generally also characterized by a greater frequency of Fritillaridae than Oikopleuridae (Table 1).

On the northern side of the island stations 3, 4, 5 and 6 form a group here called III, characterized by $O$. fusiformis, $F$. borealis and $H$. longicauda or vice-versa, $F$. pellucida, $F$. formica and $S$. magnum or vice-versa 
in decreasing percentage; and show a greater percentage of Oikopleuridae than Fritillaridae (Table 1).

Thus it can be said that the waters of the southeastern and of the northwestern approach of the island showed a different frequency composition of species of Copelata, there being a general characteristic picture of frequencies for the southern waters and another for the northern. This is also true for the general amount of representatives of the families of Copelata present.

The hydrographical data available from the literature were all taken at considerable distance from the island. Since the island is situated in the relatively strong South Equatorial Current, the prevailing hydrographical conditions found in the region as stated above, may have been locally altered by the island and the islets around it so that a certain amount of waters from deeper layers may have risen to the surface northwest of the island thus explaining the difference in the populations. Our hydrographical data all taken at zero meters show that the same salinity and temperature prevail on the northern and southern approaches of the island. This can be explained by the fact that the water from the deeper layer has already been mixed with the surface water and acquired its characteristics through the influence of the atmosphere in contact with it. Most of the plankton hauls were made in subsurface layers, the waters of which not having yet reached the surface had not entirely acquired the surface characteristics. Another explanation for the difference in the Copelata composition observed in each station may be that it is not due to hydrographical features but to different swarms of Copelata fished on the different hauls. Patchiness of plankton organisms is a well established fact (Cushing 1955, p. 25-35; Hardy 1955, p. 7-11). Other speculations on the matter are impossible with the small amount of data available. In all the samples of superficial plankton collected by net A (see Fig. 2) it can be observed that $H$. longicauda shows a slight increase in percentage when compared to that obtained at the same stations at greater depths (net B). This seems to explain the change suffered in the general percentages of species in samples M-11 (station 6), M-12 (station 7) and M-1 (station 1), when compared to the other samples collected at other depths.

$O$. dioica and $F$. abjörnseni, usually regarded as neritic species, were registered in station 2 and $F$. abjörnseni also occurred at station 7 , both stations situated on the island shelf. Lohmann (1896, p. 109) also observed the occurrence of coastal animals in Fernando de Noronha waters and farther east from the island. His conclusions that there was influence from the Brazilian coast on the island does not seem to be acceptable because the South Equatorial Current flows northwesterly with sufficient strength to prevent any formation of coastal countercurrents flowing from the continent towards the east. The coastal animals observed by Lohmann may have come from the African coast via the South Equatorial Current. Like Trindade Island, Fernando de Noronha, situated in oceanic waters, has the influence of a coast on the animals which live in the waters surrounding it (Ekman 1953, p. 313). 


\section{ACKNOWLEDGEMENTS}

We are indebted to Dr. I. Emílsson for helpful suggestions and for the revision of the hydrographical part; to Dr. M. Vannucci and Mr. J. P. Carvalho for criticism of the manuscript. We also thank Dr. M. Vannucci and Dr. E. F. Nonato for collecting the material used in this study.

\section{S U M A R I O}

Durante uma viagem à ilha Fernando de Noronha em Janeiro de 1954, a Dra. M. Vannucei e o Dr. E. F. Nonato coletaram amostras de plancton em várias estações ao norte e ao sul da ilha. A tabela 1 mostra o número das estações, sua posição geográfica, outros dados tais como salinidade, hora de coleta, profundidade local e da coleta, tipos de rêdes usados, etc., assim como o número e a porcentagem de cada espécie de Copelata encontrada em cada amostra. Comparando a população de Copelata capturada ao norte e ao sul da ilha verificou-se que havia uma diferença bem marcada nas porcentagens das diferentes espécies por amostra, e que as águas do sul e do norte da ilha mostraram um quadro diferente de frequiêneias (Fig. 1) assim como foi diferente de cada lado da ilha a porcentagem das Famílias Oikopleuridae e Fritillaridae. Estas predominaram ao sul enquanto aquelas predominaram ao norte da ilha.

Para êstes fatos existem duas explicações possíveis: - ou a ilha funcionou como obstáculo às águas da Corrente Sul Equatorial provocando no seu lado noroeste uma subida de água das camadas inferiores e modificando assim as condições hidrológicas características da região, ou as diferenças observadas de amostra para amostra (Fig. 2) foram devidas não a diferenças hidrológicas, mas, sim a diferentes "nuvens" de Copelata que ocorreram ao norte e ao sul da ilha, durante a época em que foi feita a coleta.

$H$. longicauda mostrou ligeiro acréscimo na porcentagem relativa às outras espécies, quando coletada com rêde pelágica (A) na superfície, quando comparada com as porcentagens em que ocorre em amostras coletadas por outras rêdes em profundidades maiores.

A ocorrência de espécies neríticas ( $O$. dioica e $F$. abjörnseni) nas estações mais próximas da costa $(2$ e 7 ) ambas situadas sôbre a plataforma insular, não vem confirmar a idéia de Lohmann (1896, p. 109) de que haja influência da costa brasileira sôbre a ilha, pois a intensidade da corrente Sul Equatorial nessa região em direção NW torná-la-ia muito improvável, e sim confirma a teoria de Ekman (1953, p. 313) de que as pequenas ilhas oceânicas agem como costas.

As estações ao norte da ilha mostraram como população de Copelata característica nestas amostras, em porcentagem decrescente as espécies $O$. fusiformis, $F$. borealis e $\boldsymbol{H}$. longicauda ou vice-versa, $\boldsymbol{F}$. pellucida, e $F$. formica e $S$. magnum ou vice-versa ; as do sul da ilha, freqüências elevadas de $F$. borealis, $H$. longicauda e porcentagens menores de $O$. fusiformis, $F$. pellucida e $F$. formica.

\section{R E F E R E N C S}

CUSHING, D. H. - 1955. Production and a Pelagic Fishery. Fishery Investigations, Ser. II, Vol. XVIII, n. ${ }^{\circ}$ 7, I-VI + 104 p. - Ministry of Agriculture, Fisheries and Food.

DEFANT, A. - 1936. Die Troposphaere. Schichtung und Zirkulation des Atlantischen Ozeans. Wissensch. Ergeb. Deutsch. Atlantischen Exped. ("Meteor"), Bd. VI, Teil 1., p. 289-411, 28 Abb. im text, 19 Beil. 
EKMAN, S. - 1953. Zoogeography of the Sea. XII + 417 p., Sidwick \& Jackson Ltd. London.

HARDY, A. C. - 1955. A further example of the patchiness of plankton distribution. Papers in Mar. Biol. \& Oceanography. Deep-Sea Research Suppl. to Vol. 3, p. 7-11.

HENTSCHEL, E. - 1933. Allgemeine Biologie des Südatlantischen Ozeans. I Das Pelagial der Obersten Wasserschicht. Wissensch. Ergeb. Deutsch. Atlantischen Exped. ("Meteor") 1925-27, Bd. XI, p. 1-168, 67 Abb. im text, 8 Beil.

LOHMANN, H. - 1896. Die Appendicularien der Plankton-Expedition. Ergeb. Plankton-Exped., Bd. 2 E. c., p. 1-148, 20 taf., 30 Kart., 1 Diagr.

LOHMANN, H. \& HENTSCHEL, E. - 1939. Die Appendicularien im Südatlantischen Ozean. 1 - Die Horisontal Verbreitung der Wichtigsten Arten. Wissensch. Ergeb. Deutsch. Atlantischen Exped. ("Meteor") 1925-27, Bd. XIII, p. 154-182, 95-117 Abb. im text.






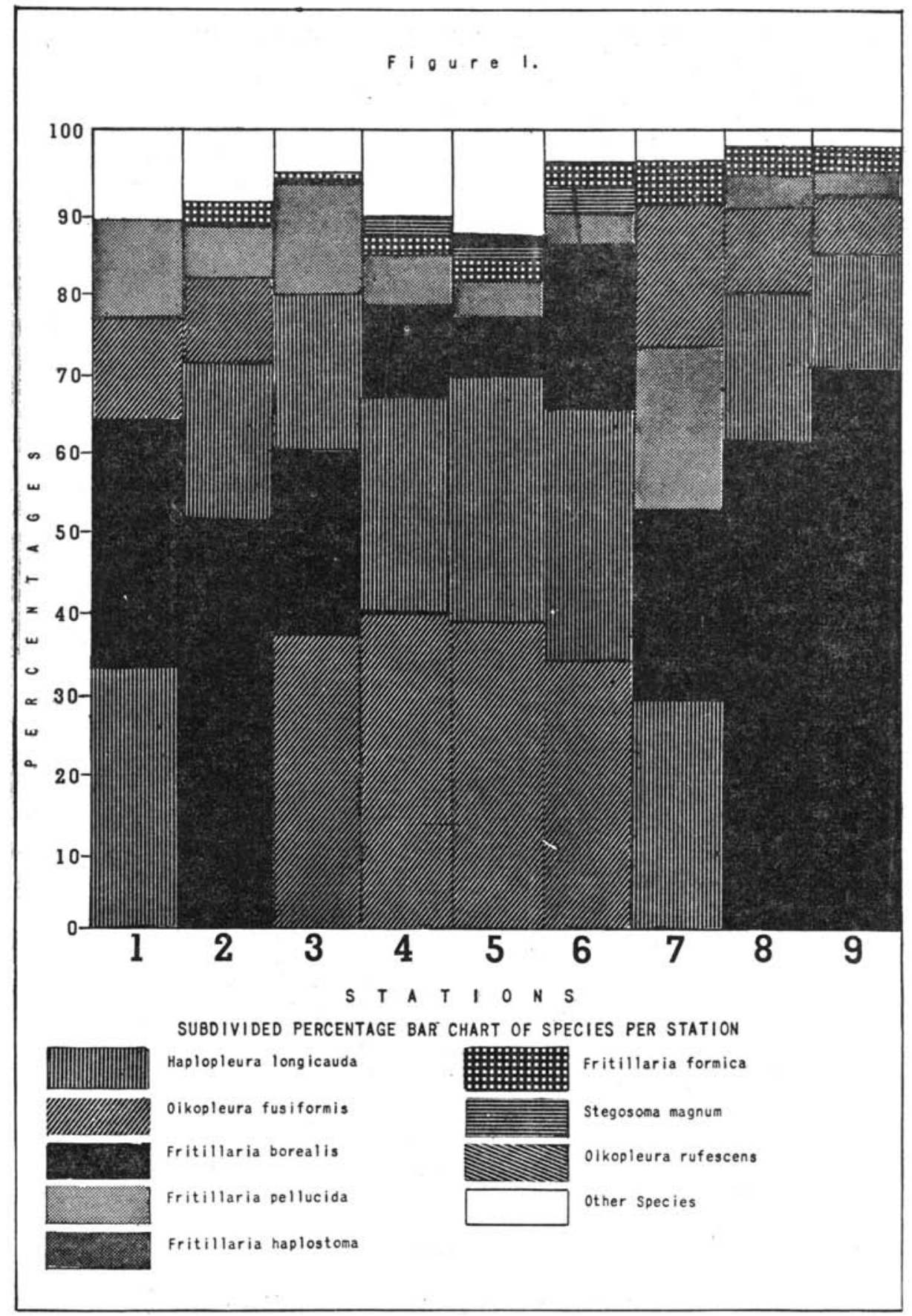









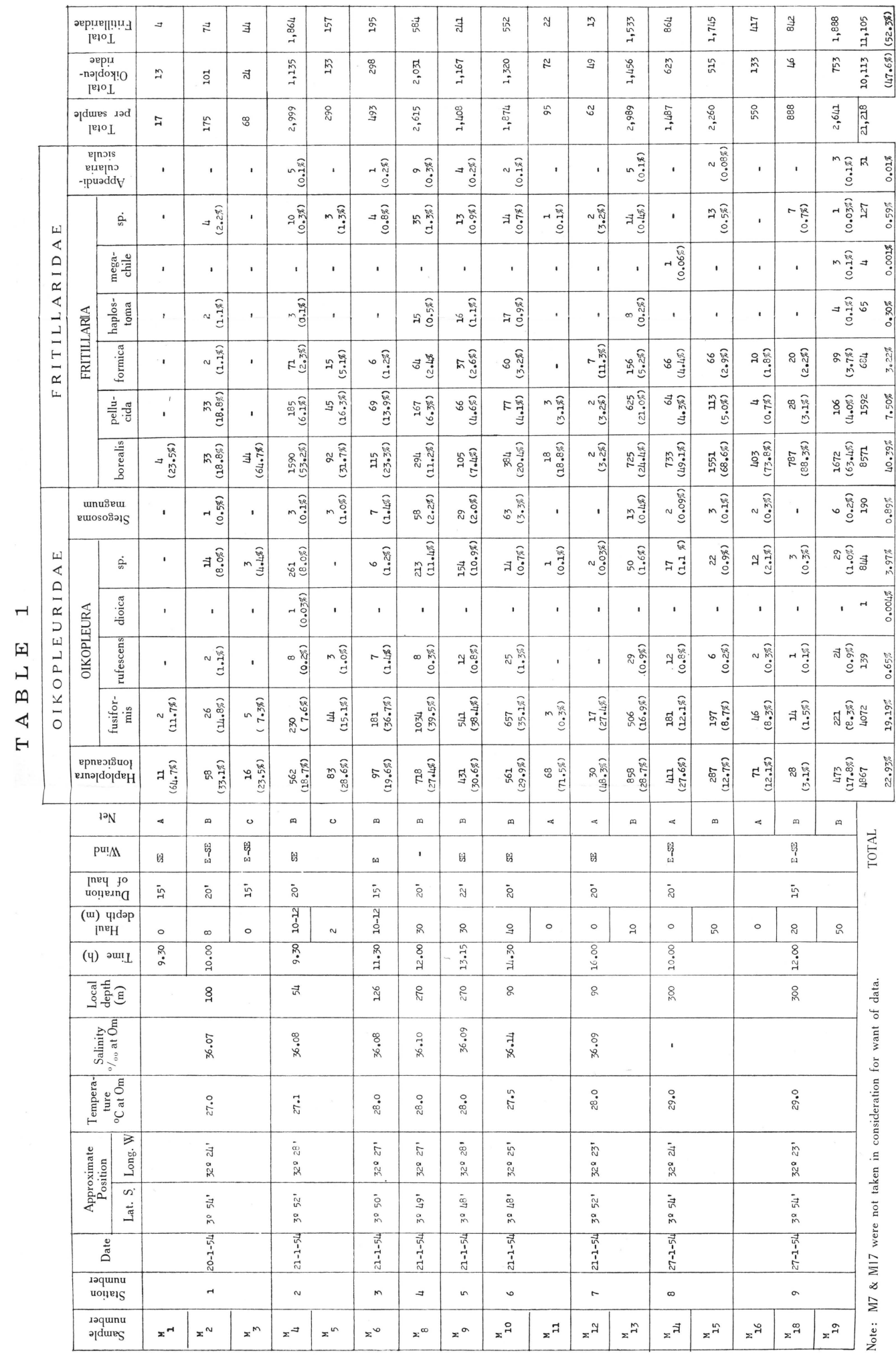

